\title{
History of the Ceylon Journal of Medical Science (CJMS)
}

\author{
R.L. Jayakody \\ Professor of Pharmacology and former Co-Editor of the CJMS \\ Department of Pharmacology, Faculty of Medicine, University of Colombo
}

DOI: http://doi.org/10.4038/cjms.v54i1.4801

The Ceylon Journal of Medical Science had its beginning as Section D of the Ceylon Journal of Science in 1924. The Ceylon Journal of Science was established by the Government of Ceylon for the publication of scientific and other research conducted in the colony. The journal published scientific matter, pure and applied, that had relevance to the natural and other products of the Island. The botanical, zoological and some other sections had been in existence as separate Journals for many years, but these were consolidated into the Ceylon Journal of Science in 1924. At that time the Journal consisted of seven sections: Section A Botany, Section B - Zoology and Geology, Section C - Fisheries, Section D - Medical Science, Section E - Mathematics, Physics and Meteorology, Section F - Chemistry and Section G - Archaeology, Ethnology [1].

For the purpose of general administration, the journal was controlled by an Editorial Board. Each Section was a separate publication with its own editor (identified as an Associate Editor), having its own pagination and appearing independently of other Sections. The first Editorial Board had 16

\section{Corresponding Author:}

R. L. Jayakody MBBS (Ceylon),LRCP, MRCS (UK), MRCP(UK), PhD (Alberta, Canada)

Professor of Pharmacology and former Co-Editor of the CJMS

Department of Pharmacology, Faculty of Medicine, University of Colombo

jayakodyrl@pharm.cmb.ac.lk members, including the Associate Editors and leaders in respective fields at that time. Dr. J. Pearson (from Section C) functioned simultaneously as the Chairman of the Editorial Board, the Editor of the Ceylon Journal of Science and the Associate Editor of Section C. Dr. Nicholls, the Director of the Bacteriological Institute of Ceylon, functioned as the Associate Editor of Section D and handled the Medical Sciences. He and Dr. R. L. Spittel served in the Editorial Board. The first publication of Section D appeared as Volume 1 Part 1 on June $4^{\text {th }}, 1924$.

Most of the early publications were from the foreign scholars in the colonial service attached to teaching and service institutes in health sector of the colony. The teachers of the Ceylon Medical College (predecessor of the Colombo Medical Faculty) and the staff attached to the Bacteriological Institute of Ceylon (predecessor of the Medical Research Institute) were figured prominently in the early volumes. Subsequently, papers from Sri Lankans (then called as Ceylonese) who became leading researchers in academic institutions, were published in this Journal. Such researchers include Drs. W.S.E. Karunaratne, P. B. Fernando, SenakaBibile, T.W.Wikramanayake, T.Velaudapillai, A.S. Dissanaike, S.R. Kottegoda, V. Basnayake, and K.N.Seneviratne. Although the papers covered diverse areas, infectious diseases in fields of malaria, leprosy, helminthiasis and tuberculosis predominated. Subjects related to anatomy, pathology and entomology were also covered.

D http://orcid.org/0000-0002-1912-8843

This is an open-access article distributed under the terms of the Creative Commons Attribution License, which permits unrestricted use, distribution, and reproduction in any medium, provided the original author and source are credited. 
Additionally, data on various surveys (diet, nutrition and other) were also presented. Such papers contained data presented as long tables. Most papers contained only raw data. Although the research methods and statistical analysis were not as robust as what we see today, these publications reflected the standard of practice at that time.

The journal has been in continuous publication until 1941 (Volume V part 3) after which a break occurred. In 1942 the Journal was handed over to the University of Ceylon and was administered by an Editorial Board appointed by the University. After a break of 8 years, Volume VI appeared in 1949 as the Ceylon Journal of Medical Science (CJMS) as two parts: Parts 1 and 2 [2]. Volume VII put out in 1950 had four parts. Similarly, Volume VIII which covered the period of 1951 to 1954, also had four parts. Though consistency in the volume number and the year of publication was not maintained, regular publication of the Journal was maintained in the 1950s, 60s and 70s, and later an attempt was made to follow a biannual pattern. Until the 1960s the teachers from the Colombo Medical Faculty handled the Journal. With the establishment of more faculties of medicine, members from these also served in the Editorial Board.
During the first half of the twentieth century not many medical journals were published in Ceylon. The Ceylon Medical Journal, and Section D of the Ceylon Journal of Science would have been among the few that appeared regularly. Hence, a scarcity of research articles for sustained publication of journals may not have been experienced. In the latter part of the $20^{\text {th }}$ century, various Colleges and Associations commenced their own journals. In addition, the university merit promotion scheme for academic staff tempted researchers to go to regional and international journals with citations in recognized indexing bodies. These made it difficult for the Editors to have a continuous supply of articles for sustained publication. Despite various attempts the CJMS publications lagged behind and the last publication (Vol 53: parts $1 \& 2$ ) appeared in 2010.

I am pleased to see that the Faculty of Medicine, University of Colombo has taken the initiative to reactivate this Journal. I wish it all success.

\section{References}

1. Editorial notes. Ceylon Journal of Science Section D 1924: Volume I; 1

2. Editorial notes. Ceylon Journal of Medical Science 1949: Volume 6; 1 